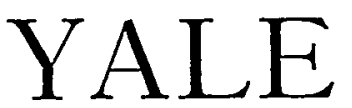

LAW JOURNAL

$\begin{array}{lll}\text { VOL. I JUNE, } 1892 & \text { No. } 6\end{array}$

\title{
SOME REMINISCENCES OF THE NEW HAVEN BAR.
}

By Hon. Frederick J. Kungsbury.

It is now just fifty years $\left(184_{2}-189^{2}\right)$ since I first came to know by sight, and later somewhat more intimately, the members of the New Haven bar.

New Haven had then a population of 15,000 (town and city), but there were few if any towns of its size that equalled it in the ability and high character of its legal leaders.

Nathan Smith, who had been one of the foremost members of the profession for many years, had died while a senator in Washington, seven years before (I835), but his memory was still fresh among his professional brethren, and many were the traditions of his impetuous and imperious power with juries, his scathing crossexaminations, his ingenious dealings with the intricacies of tech-' nical law and other details of his brilliant forensic career.

His personality was picturesque and striking. His frame was large and powerful, with a magnificent head, carried a little on one side, as if too heavy to hold erect. He had a thrilling voice, an intense manner, as he passed from keen sarcasm or sallies of humor to eloquent appeals on behalf of his client, whose cause seemed to him that of abstract justice, in a way that carried conviction or sometimes perhaps bewilderment to the jury before him.

He belonged to a family noted for its legal ability, being a brother of the distinguished Judge Nathaniel Smith, an uncle of Truman Smith the great advocate and Senator, and brother-inlaw of Judge Bennett Bronson of the County Court.

As an advocate at the bar and a man of high personal character he had few, if any superiors, and yet (such is the evanescent nature of a reputation won only, or mainly, in the trial of causes), in the recent large history of the City of New Haven, I have looked in vain for any mention of his name. 
David Daggett, Simeon Baldwin and Elizur Goodrich were still living and frequently seen upon the streets and sometimes in the court room, but they were no longer in practice.

Judge Daggett held the Kent professorship in Yale and gave lectures to the senior class. He was a tall large-framed man, a little bent with age. He wore a high bell-crowned hat, a blue dress-coat with gilt buttons, a yellow waist-coat, a white muslin cravat of many folds, knee breeches, and yellow-topped Hessian boots, and I think, although it no longer needed it, that his hair was usually powdered. Although he showed something of the feebleness which belonged to his eighty years (I may as well say for the sake of accuracy that he was born in 1764 ), a stranger meeting him would at once recognize him as a person of power and distinction. Whether at the bar of his own State or as presiding justice of its Supreme Court or in the Senate of the United States, wherever he went he had been a recognized leader.

He was a man of strong will and of positive opinions; in some cases doubtless they might be called prejudices.

When he was comparatively a young man (in $\times 799$ ), he delivered a fourth of July oration in New Haven. He took for his motto a reference to Gulliver's experience in the island of Laputa, "Sunbeams may be extracted from cucumbers, but the process is tedious." It was an ultra conservative, reactionary address which bore down hard on all the novelties and follies of the time, in which he included steam navigation. "Our coasters," he said, "will still go to New York on the surface of the Sound instead of sinking to the bottom or rising into the clouds, and they will still prefer a fair wind and tide to the greatest profusion of steam produced in the most scientific manner."

It was not till eight years after this that Fulton launched the Clermont on the waters of the Hudson. If some one in reading an old letter or newspaper should happen on the phrase "Cucumber orator" he will understand to whom it refers, as this was the title derisively applied to Daggett by people who did not agree with him, in allusion to the motto of this oration.

As a Senator, he had commanded high respect in Washington, both by the force of his intellect and his punctilious dignity of manner.

In quickness of repartee, which perhaps went for more in those days than now, he had few superiors. His lectures to the college students were instructive and were illustrated and enlivened with anecdotes, but he had lost something of his brilliancy and incisiveness, and college boys, who are always, more or less, as Matthew Arnold says, young barbarians, sometimes grew restless and restive and did not treat him with that respect which was due to his 
age and position. I think that on more than one occasion he was hurt and grieved by conduct of which they ought to have been thoroughly ashamed. I presume not one of them would willingly and deliberately have caused the old man pain; but boys are thoughtiess.

Perhaps modern athletics have taught the boys of our day better manners; or perhaps they have learned by this time that instructors are human beings who are capable of feeling insults and who highly prize the good opinion and courteous conduct of those whom they are trying to instruct. Let us hope that this is the case.

I remember one of his anecdotes of a man who sat on the roof of his house playing a violin. A passer-by shouted to him to "stop that!" but he did not stop. "Come down here and I will thrash you!" The man on the roof immediately laid aside his violin and looking down, as if accepting the challenge, said "will you?" "Yes, I will." "Well, then," said the other, at once resuming his music, "I shan't come down." Another anecdote was of a man who rushed out of a house with a red-hot poker in his hand and approaching the first man he met asked permission to run it through him, which was peremptorily declined. "Well, then," said the poker bearer, "into you, only an inch, that isn't much." This too was refused. "Then you will at least pay me something for heating the poker."

I do not remember now just what legal maxims these anecdotes were used to illustrate; but they are evidently of very general application. One of the Latin mottoes which he was fond of writing in the boys' autograph books was "Summum jus est summa injuria," the sound sense of which I have never been able to see, unless you apply it to a man who is hanged, although I am aware that a different interpretation has been given.

Judge Simeon Baldwin was not so picturesque a character as Daggett. He dressed in the fashion of other men of his time. He was a solid and substantial citizen, of medium height, rather stout, with a broad, serene, judicial face that betokened a mind at ease, a thorough genuineness of nature, an unconsciousness and entire absence of any effort at effect. He, too, had held many important offices and enjoyed the thorough respect and confidence of his fellow citizens, evidenced in many ways through a long life. He had now ceased to attend to business and was passing a calm old age, thoroughly enjoying the success of his more distinguished son. He was a pleasant man to meet upon the street where he was always received with respectful deference.

Elizur Goodrich resided with his son Rev. Professor Chauncey 
A. Goodrich on Temple street, near his old friend Noah Webster, whose daughter was his son's wife. $\mathrm{He}$ was now upward of eighty years of age, but still continued to hold the office and discharge the duties of Secretary of the Corporation of Yale College, an office which he filled for thirty years, from 1816 to 1846 . His figure was slight and he was of medium height, but he had a brisk step and a remarkably alert and active carriage for one so advanced in years. At Commencement exercises he sat at the president's left hand at a table containing the degrees, six in a roll, and handed them to a page, generally a lad of eight or ten, selected for his presentable appearance and courteous manner, who in turn handed them to the president, as the candidates came forward, six at a time, to receive them. The last page under Mr. Goodrich's administration was Master Simeon E. Baldwin. Mr. Goodrich had been a leading lawyer for many years and had filled a great number of important offices, but, with the exception of his secretaryship, he had at this date long retired from public life. His time was spent in reading the papers, the classics of which he had a thorough knowledge, in conversation which he always made interesting and instructive, and in a daily constitutional walk.

Turning now from these lights of other days, full of years and honors, who were enjoying a well-earned rest and a tranquil old age, we come to the men who were in active practice as leaders of the bar. Speaking of them once to a leading lawyer in one of our largest cities, I remarked, "we regard those men very highly in Connecticut." "Well you may," was the reply ; "They would be among the leaders at any bar in the world."

The four men who were the acknowledged leaders of the New Haven bar at that time were Ralph I. Ingersoll, Dennis Kimberly, Roger S. Baldwin, and Charles A. Ingersoll.

I have named them in the order of their respective ages. There was but little difference in the ages of the first three and they were about fifty : the last-named was several years younger.

Two or more of them, and not infrequently all four, were engaged in the trial of nearly every important case that came before the New Haven Court.

Charles A. Ingersoll, however, was clerk of the U. S. District Court, and the passage of a general bankrupt law, not long before, had rendered the duties of this office so arduous and so profitable, that for some years he seldom appeared in the trial of litigated causes.

When this pressure was over, he returned to practice until 
I853, when he was appointed judge of the U. S. District Court for this District. Although he was the youngest of the famous quartette, and began his practice later and left it earlier than the others, and for this reason is not so closely associated with them in my memory as the other three are with each other, I will say what I have to say about him first. He was a strikingly handsome man. Full six feet high, of fine figure, erect, well knit, with no superfluous flesh, a large head with a forehead of great breadth, surmounted by graceful locks of greyish hair; finely cut and strongly marked features; much dignity of bearing and a manner somewhat stern, he looked a very Rhadamanthus on the bench. No criminal or accused person ever took much comfort I fancy, in looking at him either on the bench or when he was prosecuting attorney, which office he held some years. He did not look as if sympathy were any part of his role. Yet, he was not unkindly, nor always stern, and occasionally would permit himself to enjoy a joke in a dignified way, but he.was not a man to be trifled with; one felt sure of that. His handsome mouth closed with a firmness very discouraging to people with whom he differed. He had a way of picking up some inconspicuous phrase in a contract or some accidental statement of a witness and emphasizing it, magnifying it, dwelling upon it, until it seemed really the most important thing in the case.

This was sometimes done with great effect. He had great tenacity and did not enjoy yielding. On one occasion the four were engaged in an important and hardly contested suit. The trial had been long and tedious. The evidence was mostly in, but for some purpose, perhaps the introduction of some rebutting testimony, the counsel were changing places at the long table.

The two Ingersolls were on one side, Baldwin and Kimberly on the other. Baldwin and R. I. Ingersoll were always on the best of terms and as they passed each other, Baldwin said to Ingersoll in a low tone: "You are beaten, why don't you give up?" "I know, I know," said Ingersoll, "but Charley won't." Of course he was compelled to give up in the end, but he preferred to find it out from the court and jury rather than acknowledge it himself. He made an able and excellent federal judge, always maintaining to the full and without apparent effort, the dignity of the court. He held frequent terms in the New York District, as our Connecticut judges have always done, and was regarded there with profound respect.

Ralph I. Ingersoll was quite unlike his brother in appearance. $\mathrm{He}$ was of medium height, but very slender, with delicate hands 
and feet. His head, though of good size, was made to seem rather small by his long neck. His features were not regular and the skin of his face was deeply lined and wrinkled. He was not what would have been called a handsome man, but there was about him an air of refinement, of great delicacy and of high breeding, most noticeable and attractive. I think few men would have ventured to relate a vulgar story in his presence. I can remember well the extreme delicacy of his hands and a grace in the position of his fingers on the back of an open book as he held it face downward while addressing the court.

His whole personality was attractive. His usual dress was black and he wore a frock coat. His garments were spotlessly neat and well fitted. His arms were so slender that the sleeves seemed a little loose, but they were so gracefully worn that you did not wish them to fit closer. He reminded me of pictures that I have seen of old French noblemen, showing the results of many generations of refinement and high breeding. Indeed there was something French in the manner of the man. His habitual expression was thoughtful, but he had a look of amused good nature, which, while not quite a smile, was still very attractive.

While he commanded respect, there was, also, something in his manner which invited confidence and no one felt hesitation in opening his heart to him, feeling sure that he would meet with ready sympathy. He was always kind and encouraging to young men and the younger members of the bar were very fond of him. His manner before the court was quiet, refined and dignified. He was a skillful and successful cross-examiner, but he was never rude nor brutal in his methods. After having judiciously wound the witness up in a snarl of perplexity, he looked on with an air of amused pity, as if to say, "Isn't there some way in which I can help you out of this tangle in which you seem to have involved yourself?" Generally that sympathetic look so warmed the witness' heart and threw him off his guard, that he went on getting deeper and deeper in.

His method of conducting a case, his manner of addressing the court, his treatment of opposing counsel were all models of legal courtesy and as nearly perfect as can well be imagined.

Roger S. Baldwin was tall, fully six feet in height, and rather heavily built. I never heard one of these men placed above the other in their legal standing. They each had their strong points, but probably for pure knowledge of the science of law, if the opinion of the others had been asked, they would have freely given Baldwin the pre-eminence. In imagination and a sense of 
humor, they were probably his superiors and for this reason better fitted to deal with a jury.

But neither of the four were remarkable in their sense of humor. They never tried their cases to the audience. They indulged in a certain sort of grim professional humor sometimes, but it was rare.

The duty of a lawyer has been well defined to be "to assist the court in coming to a right decision." This was their view of it and this duty they discharged.

No oratory or rhetoric that would not tell on the court or jury was ever wasted by these men in the trial of a case. How they managed with the more versatile and sparkling style of Nathan Smith or how they would have got along in trying cases with Rufus Choate, it is somewhat difficult to imagine, but they suited each other admirably.

I remember a little incident somewhat characteristic of these peculiarities, or at least one which brought them out rather strongly. A young scapegrace had involved himself in some peccadillo which rendered him liable to criminal prosecution. He had wealthy friends in another part of the State and as the only thing, probably, which they could do for him, they retained the ablest counsel for his defense. He was imagined to have made some damaging admissions to one of the underkeepers at the gaol where he was taken after his arrest.

This young man, the underkeeper, was on the witness stand; C. A. Ingersoll being prosecuting attorney. After a few preliminary questions, fixing time, place, etc., he asked: "And what did he say to you?"

"Stop a minute," interrupted Gov. Baldwin, "we object to this question, if the court please." And he went on with a statement of his objection, fortifying his position with a learned argument; this was replied to by Gen. Kimberly on behalf of the prosecution and something further was added by the two Ingersolls one on each side. They were doing their best and the discussion must have lasted half an hour. When it had ended the judge said: "You may ask the question, Mr. Ingersoll." "Well, what did he say." "Not one solitary word," said the witness, who had evidently been biding his time with anticipations of an impending sensation. The whole court room rang with laughter. Lawyers, jury, spectators and even the judge joining in it, the denouement was so farcical and so unexpected.

But these four men who were trying the case, somehow, all looked as if they had been imposed upon and trifled with. They 
smiled to be sure, but it was with that sickly smile of ceremonious disgust that indicated no interest whatever; and the case went on its way.

A few years before the time of which I write, Gov. Baldwin had made for himself a national reputation by his masterly argument in the Amistad case. Doubtless he enjoyed to the full his success, but so far as I now remember he never permitted the slightest demonstration of a personal nature to emphasize that great victory. To do such a thing was wholly foreign to his nature and would have given him pain instead of pleasure. His manner was rather formal, his features had little play, his figure was as sturdily upright as his character, and about as hard to bend. But his periods were polished and graceful, his diction pure, his sentences well balanced and flowing. In short he was a master both in language and style. Sometimes, when he was examining the work of his juniors, he would criticize certain words or forms of expression. He always accompanied this with a statement of the reasons and his manner was so thoroughly kind and his criticisms so sound and well founded, that they were sure to be received and accepted with pleasure.

He did not seem to have an especially quick or facile mind, but rather to have built himself up by strong intellectual power and great application. He was a constant and unwearied student.

Perhaps General Kimberly had more of what might be called genius than either of the others. Comparing the methods of the two men, an able lawyer once said: "If Governor Baldwin has a difficult case he goes to his office and studies and studies and pores over it until he has mastered the whole subject. If General Kimberly has a difficult case he goes to bed and thinks and thinks until he has made up his mind how it ought to be and then he looks up the cases to see if the others have found it out." Though somewhat exaggerated, as of course any such characterization might be expected to be, there is doubtless a valuable suggestion in it as to the mental processes and peculiarities of the two men.

Governor Baldwin built upon his knowledge of legal principles and the elucidation of those principles in cases and opinions. General Kimberly built on his sense of the eternal fitness of things and the way in which that sense could be made to express itself to the average man, be he judge or juryman. The former argued his case as before omniscience; the latter as before an average judge or jury.

General Kimberly was a large man, tall and broad shouldered, somewhat loosely built and of rather slow, easy motions. He had 
a deep capacious voice, of a good deal of flexibility and an unctuous, comprehensive, paternal tone, very agreeable to listen to in conversation and well fitted for the purposes of the court room. $\mathrm{He}$ was scrupulously neat in dress and rather fond of color, his favorite costume being a claret-colored frock-coat, white waistcoat and lavender trousers. His military days were over when I knew him, but he must have been a fine figure on horseback at the head of his brigade. He refused a senatorship, preferring his bachelor quarters at the Tontine and his daily round of professional duties to any allurements of the more conspicuous position.

The attraction in these men in addition to ability of high order was their strong sense of personal and professional honor, their unquestioned integrity, and their thorough respect and affection for each other. I remember on one occasion something transpired in the course of a trial (I regret that I cannot now recall the circumstances), which, had it been known to the counsel, before hand, and it might have been, would have seemed somewhat dishonorable or unfair. I think it was Governor Baldwin, who immediately arose to say with some emphasis that he had not been aware of the fact. Mr. Ingersoll sprang to his feet in a moment. "We know you were not. We never for an instant supposed that you were," said he. And there was something in the tone of his voice which expressed absolute pain that his lifelong friend should have thought him capable of such suspicions.

When we reflect that $\mathrm{Mr}$. Ingersoll was not a man who was given to extravagancies of expression or in the habit of saying more than he meant, there are some most notable utterances in the remarks made by him at the meeting of the bar held on the occasion of Governor Baldwin's death. I will give two brief paragraphs.

"I know, ve all know, that the man never lived who felt his causes more thoroughly than Governor Baldwin; I also have my feelings, perhaps they were more ardent formerly than now, but it is one of the consolations of my life, one of my best and most consoling reflections that during that long practice, the first word of unkindness, the first discourteous sentiment or look never, never passed between us."

\section{And again :}

"This, I will say, as I cling to life with the tenacity that human nature with all its infirmity does, and unfit as I feel myself to enter the future, yet sir, could I feel in conscience that I had the purity, the spotless integrity, the Christian virtues of this distinguished gentleman who now sleeps in death, much as I dread the future, I would willingly agree now that my poor frame should this day be enclosed in its coffin." 
These brief and superficial sketches are not intended to be either biographical or critical. They are simply the result of an attempt to reproduce from memory after a lapse of half a century some of the more vivid impressions made upon the youthful mind by these great and good members of the profession.

To the younger men who did not know them, the meagre outlines here given will not go far in assisting the imagination to reproduce their personality; but with some of those who have their own recollections, as a background and reinforcement, I trust there may be some associations awakened and memories aroused upon which it may be pleasant to dwell for a passing hour, and to none can this reminder of what the profession is capable of be without its value. 